\title{
Sustainable Use and Management of Natural Resources in Construction: The Importance of Recycling
}

\author{
E Conte* \\ DICATECh, Polytechnic University of Bari, Italy \\ Submission: January 25, 2021; Published: February 03, 2021 \\ *Corresponding author: E Conte, DICATECh, Polytechnic University of Bari, Bari, Italy
}

Abstract

The saving of raw materials to reduce the consumption of non-energy resources, beyond fossil fuels, and the amount of waste to send to landfill have an interest in the construction sector, which is one of the main consumers of these resources. This interest recalls the importance of recycling. This short paper discusses a number of factors influencing the strengthening of recycling, based on the author's multi-year studies and research on sustainable buildings.

Keywords: Recycling in construction; C\&D waste, Saving of raw-materials

\section{Introduction}

The approach used in buildings and in the construction sector in general towards sustainability has been mainly incremental, as have innovation efforts [1]. For decades, the issue of energy efficiency has been dominant in reducing fossil fuel consumption and environmental pollution, and more needs to be done [2]. Recently, other issues have arising interest, including the saving of raw materials to reduce the consumption of non-energy resources, beyond fossil fuels, and the amount of waste to send to landfill. This interest recalls the importance of recycling, an activity that can also respond positively to the principles of the circular economy, if managed effectively [3]. The legislation also started to force in this direction [4]. However, the current situation in the construction sector [5] shows that both conceptually and practically the logic of recycling has not yet been well understood, largely limiting the recycling potential in contributing to the saving of natural resources.

\section{Discussion}

Recycling is a practice that is now gaining ground for its positive effects on the natural environment, also improving the economy [6]. Similarly, in the constructions sector, recycling is not new [7], emphasized by the LCA (Life Cycle Assessment) approach [8]. Therefore, C\&D (Construction and Demolition) waste recovery has reached considerable rates at present, at least in Europe [9]; but most recovered materials are used for low-value construction work, such as filling excavations and roads, and therefore it is necessary to increase the quality, not only the quantity, of the recycling of C\&D waste [10]. In addition, recycling is mainly off-site than in-site. Many factors influence this situation [11]; among them, some are of interest here: the original materials that compose $\mathrm{C} \& \mathrm{D}$ waste, the original construction techniques, the cost of waste treatments, the insufficient research and application of treatment processes in the construction sector, the lack of preparation of the actors involved in the construction process, the weakness of legislation.

It is also necessary to consider that the same principles of sustainability in the conservation of resources that push for recycling, also call for the reuse of buildings already built for as long as possible [12], in order to promote land conservation and reduce C\&D waste generation [13]. This means repeatedly doing construction work on existing buildings over time, each time producing a certain amount of C\&D waste, while demolition is desirably delayed for decades. It is then evident that a more synergic effort is necessary to improve recycling activities, both in-site and off-site. As long as recycling in construction is not supported by a strong and comprehensive vision that considers the entire construction value chain [14], it remains weak and constantly under the influence of manufacturers of building materials who promote their products as sustainable because they contain a percentage of recyclable/recycled material. Of course, this is favorable, but it is neither enough nor always really sustainable [15]. 
With regard to the original materials that compose C\&D waste, one of the most important obstacles for high-value recycling is related to the original construction technique: if it requires wet operations, such as walls built of bricks and mortar, the selective demolition separating the basic materials increases costs [16] and is time-consuming. As a result, waste collected from nonselective demolition is 'dirty', greatly reducing or even zeroing their value for the production of second raw materials - unless they are subjected to adequate treatment processes with related costs - favoring their destination as low value material (usually aggregated) for construction works. When disassembly is made possible because dry construction techniques are originally used, basic materials and components are collected more easily and effectively and redirected to reuse/recycling. However, for several reasons, it is common for them to be directed towards basic recycling treatment processes, such as steel, wood, glass, PVC, etc. [17], rather than undergoing maintenance and adaptation operations capable of making them reusable in the same or other construction sites as second-hand materials and components, such as beams, windows, tiles, etc.

Treatment processes are also very important to improve recycling [18], both in terms of costs and technologies capable of producing second raw materials for construction. Many waste recycling treatment processes are studied and implemented outside the construction sector, as is the case with plastic or tires; sometimes they help produce construction products, such as recycled polypropylene elements for creating crawl spaces or recycled rubber aggregates for composites. Things have changed since the legislation began to introduce the obligation to respect a certain percentage of recycled materials in construction products, at least for public investments (see, for example, the Italian case of Minimum Environmental Criteria [19]). This is increasing the commitment of manufacturers in the study and implementation of new operational technologies for waste treatment processes in the construction sector, also helping to lower the cost of products otherwise higher than that of raw materials. However, research and application of treatment processes in the construction sector remain insufficient, as they are directed mainly by legislative requirements and producer interests rather than, or in addition to what may be most effectively needed in construction sites. This is evidenced by research and production efforts that remain quite localized and under-used although significant in terms of eco-innovation (see, for example, Rebrick, an EU-funded project for the reuse of clay bricks from the demolition of old walls in buildings [20]).

An important role in this context is played by the lack of preparation of the actors involved in the construction process who usually follow normative indications, such as the previously mentioned percentage of recycled materials to be respected in public constructions, without grasping the real possibility inherent in recycling to modify the design and construction processes [21], in new constructions as well as in the renovation of existing ones, even more important nowadays. Therefore, there is a double responsibility: on the one hand, legislation is not at the forefront [22], simply providing threshold values but not promoting a vision of recycling; on the other hand, architects, engineers, researchers, professionals and construction companies generally do not play a dynamic, proactive role [23], asking manufacturers for new treatment processes, providing them with adequate knowledge and technologies, helping to invest and design new processes.

From this it is clear that even for recycling - as in the first place it was for energy saving - we are pursuing sustainability objectives as if one were independent of the other and the development actors can act independently, with a lot of commitment but with the result of struggling without really succeeding. Recycling for the saving of raw materials must be part of a complete vision of sustainability in the construction sector [24], and be pursued together with the use of second (and even multiple) hand materials and low-value renewable materials; it must be applied on a large scale [25], this being promoted by policies, regulations and financial measures in the construction sector [26]; it must be supported by advances in research and technology [27]; it must be re-studied by architects and engineers [28] based on original materials and construction techniques to produce new knowledge and stimulate innovation.

\section{Conclusion}

Since the introduction of the principles of sustainable development in construction, we have been proceeding step by step instead of using a systemic approach, widely recognized as effective to address the complexity of sustainability [29]. It has been so to reduce the use of fossil fuels, and it is so for other issues of more recent interest, such as recycling. Although this way of doing things undoubtedly produces improvements, they are not enough to reverse the unsustainable use of natural resources, de-pollute the natural environment and combat climate change [30]. Recycling is an important objective in the construction sector that can and must be strengthened to help to promote a systemic approach to the sustainable development of the built environment.

\section{References}

1. Eco-innovation observatory (O’Brien M, Wallbaum $\mathrm{H}$, Bleischwitz $\mathrm{R}$, Eds. 2011) Resource-efficient construction the role of eco-innovation for the construction sector in Europe. EIO Thematic Report.

2. Abergel T, Dean B, Dulac J (2017) Towards a zero-emission, efficient, and resilient building and construction sector. United Nations Environment Programme Global Status Report.

3. Di Maio F, Rem PC (2015) A Robust Indicator for Promoting Circular Economy through Recycling. Journal of Environmental Protection 6(10): 1095-1104.

4. Directive 2008/98/EC of the European Parliament and of the Council of 19 November 2008 on waste and repealing certain Directives (Text with EEA relevance). 
5. Wahlström M, Bergmans J, Teittinen T, Bachér J, Smeets A, et al. (2020) Construction and Demolition Waste: challenges and opportunities in a circular economy. Eionet Report - ETC/WMGE 2020/1.

6. George DAR, Lin BCA, Chen Y (2015) A circular economy model of economic growth. Environmental Modelling \& Software 73: 60-63.

7. Thomark C (2001) Conservation of energy and natural resources by recycling building waste. Resources, Conservation and Recycling 33(2): 113-130.

8. Yeheyis M, Hewage K, Alam MS, Eskicioglu C, Sadiq R (2013) An overview of construction and demolition waste management in Canada: a lifecycle analysis approach to sustainability. Clean Technologies and Environmental Policy 15: 81-91.

9. Villoria Sáez P, Osmani M (2019) A diagnosis of construction and demolition waste generation and recovery practice in the European Union. Journal of Cleaner Production 241: 118400.

10. Wahlström M, Rüdenhausen MC, Hradil P, Smith KH, Oberender A, et al. (2019) Improving quality of construction \& demolition wasteRequirements for pre-demolition audit. Tema Nord 2019:508, Nordic Council of Ministers/Publication Unit, Copenhagen, Denmark.

11. Iacoboaea C, Aldea M, Petrescu F (2019) Construction and Demolition Waste - A Challenge for the European Union? Theoretical and Empirical Researches in Urban Management 14(1): 30-52.

12. Langston CA (2008) The sustainability implications of building adaptive reuse. Paper presented at the Chinese Research Institute of Construction Management (CRIOCM) International Symposium, Beijing, China, pp. 1-10.

13. Häkkinen T, Helin T, Antuña C, Supper S, Schiopu N, et al. (2013) Land Use as an Aspect of Sustainable Building. International Journal of Sustainable Land Use and Urban Planning 1(1): 21-41.

14. Martos JGL, Styles D, Schoenberger H, Lahl BZ (2018) Construction and demolition waste best management practice in Europe. Resources, Conservation and Recycling 136: 166-178.

15. MacBride S (2019) Does recycling actually conserve or preserve things? Discard Studies.

16. Barbudo A, Ayuso J, Lozano A, Cabrera M, Uceda AL (2018) Recommendations for the Management of Construction and Demolition Waste in Treatment Plants. Proceedings 2(20): 1278.

17. Bohne RA, Wærner ER (2014) Barriers for Deconstruction and Reuse/Recycling of Construction Materials in Norway. In: Nakajima S, Russell M (Eds.), Barriers for Deconstruction and Reuse/Recycling of Construction Materials, CIB Publication 397, pp. 89-107.

18. Galán B, Viguri JR, Cifrian E, Dosal E, Andres A (2019) Influence of input streams on the construction and demolition waste (CD) recycling performance of basic and advanced treatment plants. Journal of Cleaner Production 236(2): 117523.

19. Bassi A, Ottone C, Dell'Ovo M (2019) Minimum Environmental Criteria in the architectural project. Trade-off between environmental, economic and social sustainability. Journal valori e valutazioni 22: 3545.

20. Simon JM (2014) REBRICK - Reuse bricks give them a new life.

21. Ferreira Silva M, Jayasinghe LB, Waldmann D, Hertweck F (2020) Recyclable Architecture: Prefabricated and Recyclable Typologies. Sustainability 12(4): 1342.

22. Giorgi S, Lavagna M, Campioli A (2018) Guidelines for Effective and Sustainable Recycling of Construction and Demolition Waste. In: Benetto E, Gericke K, Guiton M (Eds.), Designing Sustainable Technologies, Products and Policies, Springer, Cham, Switzerland, pp. 211-221.

23. Oyedele LO, Ajayi SO, Kadiri KO (2014) Use of recycled products in UK construction industry: An empirical investigation into critical impediments and strategies for improvement. Resources, Conservation and Recycling 93: 23-31.

24. Grosse F, Mainguy G (2010) Is recycling "part of the solution"? The role of recycling in an expanding society and a world of finite resources. S.A.P.I.EN.S 3(1): 1-17.

25. Adams KT, Osmani M, Thorpe T, Thornback J (2017) Circular economy in construction: current awareness, challenges and enablers. Proceedings of the Institution of Civil Engineers - Waste and Resource Management 170(1): 15-24.

26. Ghaffar SH, Burman M, Braimah N (2020) Pathways to circular construction: An integrated management of construction and demolition waste for resource recovery. Journal of Cleaner Production 244: 118710

27. Whittaker MJ, Grigoriadis K, Soutsos M, Sha W, Klinge A, et al. (2019) Novel construction and demolition waste (CDW) treatment and uses to maximize reuse and recycling. Advances in Building Energy Research.

28. Rose CM, Stegemann JA (2018) From Waste Management to Component Management in the Construction Industry. Sustainability 10(1): 229.

29. Barile S, Orecchini F, Saviano M, Farioli F (2018) People, technology, and governance for sustainability: the contribution of systems and cyber-systemic thinking. Sustainability Science 13: 1197-1208.

30. Conte E (2018) The Era of Sustainability: Promises, Pitfalls and Prospects for Sustainable Buildings and the Built Environment. Sustainability 10(6): 2092.

\section{Your next submission with Juniper Publishers} will reach you the below assets

- Quality Editorial service

- Swift Peer Review

- Reprints availability

- E-prints Service

- Manuscript Podcast for convenient understanding

- Global attainment for your research

- Manuscript accessibility in different formats ( Pdf, E-pub, Full Text, Audio)

- Unceasing customer service

Track the below URL for one-step submission https://juniperpublishers.com/online-submission.php 